\title{
Soil Resilience and Sustainability of Semi-Arid and Humid Tropical Soils of India: A Commentary*
}

\author{
M. Velayutham ${ }^{1 *}$ and D.K. Pal ${ }^{2}$ \\ ${ }^{1}$ Former Director, Indian Council of Agricultural Research-National Bureau of Soil Survey and Land Use \\ Planning (NBSS\&LUP), Nagpur, India; and Former Executive Director, M.S. Swaminathan Research \\ Foundation, Chennai, India. \\ ${ }^{2}$ Former Head, Division of Soil Resource Studies, NBSS\&LUP, Nagpur, India and Visiting Scientist, \\ ICRISAT, Hyderabad, India.
}

\section{Introduction}

Soil is a dynamic and living natural resource, which supports to produce goods and services of value to humans but not necessarily with perpetual ability against the degradative processes. It is well known that soil formation is a slow process, and a substantial amount of soil can form only over a geologic timescale. Soil misuse and extreme climatic conditions can damage self-regulating capacity and give way to regressive pedogenesis (Pal et al. 2013), and thus might lead to the soil to regress from higher to lower usefulness and or drastically diminished productivity. Such an unfavorable transformation of soils is termed as 'soil degradation'. However, soils do have an inherent ability to restore their life support processes if the disturbances created by anthropogenic activities are not too drastic and sudden, and mitigated with enough time is allowed for life-support processes to restore themselves. This intrinsic ability of soils to regenerate their productivity is called resilience (Szabolcs 1994). Therefore, soil resilience is the ability to bounce back or return to normal functioning, after adversity, for sustainable productive purposes.

Processes of soil degradation include chemical, physical and biological degradation of soils; and the interactions among these factors affect the capacity of a soil for self-regulation and maintaining productivity.

$1 *$ Corresponding Author Email: velayutham42@yahoo.co.in
Historic non - resilient soil situation leading to abandoning of the site, due to man-made soil degradation has been recorded as in the collapse of Harappan civilization of the Indo-Gangetic Plains. In present times we are witnessing it in the shifting cultivation areas of North - East India, by the rapidity with which old sites are abandoned and new sites are chosen for cultivation.

A wealth of soil information has been developed by the NARS, state government departments and ISRO. Pal et al. (2000), Bhattacharyya et al. (2013) have given a comprehensive review on this subject.

I. Soil Resilience is affected by factors such as 1. Moisture related and other physical properties mediated stresses. 2 . Nutrient supply related chemical stresses. 3. Toxic level of chemical elements. 4. Pollutants and contaminants through untreated sewage and industrial effluents and 5. Low Organic (carbon) matter content below a threshold level. Some examples are given below:

Soil resilience mediated through intrinsic soil properties such as textural composition and mineralogical make up are difficult to manipulate through land management practices, such as moisture stress and relieving it with longer release of applied water is dependent on moisture retention - release characteristics of the soil which again is conditioned by structure and texture of the soil. The 
scheduling of surface irrigation and design of the drip irrigation system is therefore dependent on the nature of the soil and its moisture characteristics.

Resilience of the soil after receipt of the first monsoon rains in the black soil (Karisal mann) areas of Tirunelveli district is dependent on the nature and quality of the soil. Farmers recognize and name those soils which come to easy workability and tillage operations as against those soils which turn into large clods and become amenable for tillage operations after a long time interval from the onset of monsoon rains (Mosi et al. 1991). Similar is the behaviour of the soils with the occurrence and its effect on seedling emergence and thawing behaviour of the soil in north India during winter months. The resilience of the soil for providing nutrient supply to plants within the range of "available soil nutrients" is moderated through the soils. The quantity intensity $(\mathrm{Q} / \mathrm{I})$ relations for $\mathrm{P}$ and $\mathrm{K}$ soil nutrients and the nature of Electro Ultra Filtration (EUF) fractions of soil K which differ between different kinds of soil and between soils of same kind, determine the behaviour of the soils for managing long term soil nutrient management and adoption of Integrated Plant Nutrient Supply System (IPNS). Soil test based IPNS strategy for prevailing crop rotation taking into account the nutrient buffer capacity of the particular soil type should be the management strategy for maintenance of soil fertility over time.

The data from plots of Long Term Fertilizer Experiments (LTFE) and Long Term Crop Rotation Experiments in the agricultural research stations provide research scope for unraveling the differential resilience characteristic of the unmanured and differentially manured plots of the soil and between different kinds of soils, in terms of soil mediated yield trends over time series of similar cropweather seasons and the expressions of soil resilience in maintaining soil quality and yield trends.

\section{Organic Matter in Soil}

The organic matter of the soil is the life giving entity to the soil and the soil-borne flora and fauna. The Royal Commission of Agriculture (1928) concluded that the organic carbon status of Indian soils have come to an equilibrium with prevailing climatic conditions and land management practices followed.
Studies made by Jenny and Raychaudhari (1960) and analysis of LTFE data by Swarup et al. (2000) shows that there is depletion of soil organic matter in soils of India over time. It is recognized that only when the organic carbon content is above the threshold level its beneficial effects on soil resilience will be more pronounced and manifested. The wide spread problem of soil degradation is directly related to the lower soil organic carbon concentration in the soils of India.

The following commentary and discussion is related to the physical (soil loss due to water erosion) and natural chemical degradation caused by two extreme climatic conditions i.e. semi-arid (SAT) and humid tropical (HT) climates.

\section{Physical and chemical degradation in Indian semi- arid tropical (SAT) soils}

\section{Physical degradation - soil erosion}

Under the SAT environments, the red ferruginous (RF) soils of Indian states suffer soil loss due to erosion, and the loss is maximum in Karnataka (49\%) followed by Andhra Pradesh (40\%) and Tamil Nadu (20\%) (ICAR-NAAS 2010), considering soil loss $>10 \mathrm{t} \mathrm{ha}^{-1} \mathrm{yr}^{-1}$ (using the empirical Universal Soil Loss Equation (USLE) to estimate spatial variations of soil loss factors like R, K, L, S, C and P factors) as the threshold for soil degradation. The RF soils of SAT dominantly belong to Alfisols, and the other soil orders are Inceptisols, Entisols and Mollisols (Pal et al. 2014). Considering the rate of soil formation in dry environments at $<.25 \mathrm{~mm} \mathrm{yr}^{-1}$ (Kassam et al. 1992), SAT Alfisols would gain soil at least 3.67 tha $^{-1} \mathrm{yr}^{-1}$. However, short-term hydrological studies on small agricultural watershed on Alfisols at the ICRISAT Center, Patancheru, India indicate an average soil loss from SAT Alfisols under traditional system is around $3.84 \mathrm{t} \mathrm{ha}^{-1} \mathrm{yr}^{-1}$ (Pathak et al. 1987). On the other hand, the results from long-term study reported an annual soil loss of $4.62 \mathrm{t} \mathrm{ha}^{-1} \mathrm{yr}^{-1}$ (Pathak et al. 2013). To reduce unwarranted soil loss of the SAT Alfisols, improved system of management developed by the ICRISAT (Pathak et al. 1987) made Alfisols resilient as reflected by the minimized soil loss to nearly $1 \mathrm{t} \mathrm{ha} \mathrm{hr}^{-1} 1$ and simultaneously increased crop productivity compared to traditional system on a sustained manner. These results suggest that a threshold value of soil loss by water erosion as sign of degradation, need be based on pedogenesis and experimental results rather than assuming 
an arbitrary value of $>10 \mathrm{t} \mathrm{ha}^{-1} \mathrm{yr}^{-1}$ to avoid unwarranted national expenditure for the current and future conservation measures (Pal et al. 2014).

\section{Chemical degradation-formation of $\mathrm{CaCO}_{3}$ and sodicity}

Although selected pedogenic processes such as laterization, hard setting, fragipan formation and clay-pan formation are hitherto considered as natural soil degradation processes as they lead to less desirable physical and chemical conditions, causing degradation of soils (Hall et al. 1982), the majority of the information on soil degradation at national (Sehgal and Abrol 1992, 1994), regional (FAO 1994) or international level (Oldeman 1988; UNEP 1992) has focused only on degradation caused by anthropogenic activities.

In the report of FAO (1994) on land degradation in south Asia, the potential effects of global climatic change to cause degradation in soils was not considered. It was however envisaged that if adverse changes occur in some areas, then these processes will certainly constitute a most serious form of human-induced degradation of natural resources. As a matter of fact, climate change from the humid to semi-arid did occur during the late Holocene period in major parts of the Indian sub continent (Pal et al. 2012a, 2013; Srivastava et al. 2015). It is quite likely therefore that the current aridic environment prevailing in many parts of the world including India might create adverse physical and chemical environment, leading to reduced productivity of soils. A few recent reports on major soil types (IndoGangetic Plains or IGP, Red Ferruginous and Deep Black Soils) from the Indian Council of Agricultural ResearchNational Bureau of Soil Survey and Land Use Planning (ICAR-NBSS\&LUP), Nagpur, India showed that the regressive pedogenesis (Pal et al. 2013) in terms of the formation of the pedogenic $\mathrm{CaCO}_{3}(\mathrm{PC})$ and concomitant development of sodicity and accumulation of relatively higher amounts of exchangeable Mg (EMP) than that of exchangeable $\mathrm{Ca}(\mathrm{ECP})$ in soils, is also a natural chemical process of soil degradation in SAT climatic conditions (Balpande et al. 1996; Pal et al. 2000, 2001, 2003, 2006, 2012a; Vaidya and Pal 2002; Chandran et al. 2013). Such a precise account of regressive pedogenesis in terms of factors of natural chemical degradation in major soil types of India forms a robust database for reference (Pal et al. 2009, 2012a, 2014; Srivastava et al. 2015) to expand the present knowledge on natural chemical soil degradation and to protect the livelihood of humankind.

Thus a new research initiative to identify the changes in soil properties in the SAT due to climate change can help in expanding our basic knowledge in pedology and thus provide opportunity to develop relevant database (Pal et al. 2009). Such a database could be important for adapting sustainable soil management and long-range resource management strategies for many developing nations in the arid and semi-arid regions of the world, especially in the Indian subcontinent, where arid and semi-arid environments cover more than $50 \%$ of the total geographical area (Pal et al. 2000).

\section{Physical and chemical degradation in Indian HT (Humid Tropical) soils}

\section{Physical degradation-soil erosion}

Soils under HT climate of NEH (north-eastern hills) and southern peninsular areas are most affected by water erosion, and the highest area under this category of degradation is in Nagaland (87\%), followed by Meghalaya (78\%), Arunachal Pradesh (73\%), Assam (66\%), Manipur (53\%), Tripura (38\%), Sikkim (37\%) and Kerala (15\%).These estimates were based on an assumption that soil erosion $<10 \mathrm{tha}^{-1} \mathrm{yr}^{-1}$ generally does not significantly affect soil productivity; and the HT soils with this amount of loss were not considered degraded (ICAR-NAAS 2010). The rate of soil formation varies from $<0.25 \mathrm{~mm} \mathrm{yr}^{-1}$ in dry and cold environments to $>$ $1.5 \mathrm{~mm} \mathrm{yr}^{-1}$ in humid and warm environments (Kassam et al. 1992). If the rate of soil formation is taken as $2.0 \mathrm{~mm} \mathrm{yr}^{-1}$ for soils of HT climate, the amount of top soil formation would be around $29 \mathrm{t} \mathrm{ha}^{-1} \mathrm{yr}^{-1}$ (Bhattacharyya et al. 2007). This gain in soil strongly suggests that the rate of soil loss by water erosion from Ultisols, Alfisols, Mollisols and Inceptisols is not at all significant (Bhattacharyya et al. 2007). The pedogenetic processes in HT soils, which are not given due consideration while following the USLE for estimation of soil erosion, ensures the positive balance of soil formation, and thus mature soils (like Ultisols, Alfisols, Mollisols and clay enriched Inceptisols) on a stable landscape under HT climate is a reality. The major pedogenetic processes that are operative to give rise to these soil orders, are evident through the addition of $\mathrm{C}$ by litter falls and its accumulation as soil organic matter under adequate vegetation and climate, 
translocation of clay particles (to form clay enriched B horizons) and transformation of 1.4 minerals to $1.4-0.7 \mathrm{~nm}$ mixed layer minerals which are not pure kaolinite but are kaolins with a basal spacing of around $0.7 \mathrm{~nm}$ (Pal et al. 2014). In contrast, in acidic soils (mainly Entisols) on higher slopes (ridges, scarps and terraces) under low vegetation with only shrubs and bushes, soil development is greatly hampered by the severe soil loss due to water erosion. Soil loss is also evident in other soils that have less vegetative cover. Besides proper mechanical conservation measures, such soils areas may be suitable for forestry, horticultural and plantation crops to build resilience in them (Bhattacharyya et al. 1998, 2007).

\section{Chemical degradation-soil acidity}

Development of acidity in soils is indeed a sign of natural chemical degradation due to profuse chemical weathering under HT climate. Acid soils of the HT climate have less soil fertility. Such soils with strong $(\mathrm{pH}<4.5)$ and moderate acidity ( $\mathrm{pH} 4.5-5.5)$ only were considered and they occupy about $6.98 \mathrm{~m}$ ha which is about $9.4 \%$ of the total geographical area of the country (ICAR-NAAS 2010). Soils of HT climate in the states of Kerala, Goa, Karnataka, Tamil Nadu and North Eastern Hill (NEH) areas are strong to moderately acidic Alfisols, Ultisols and Mollisols and their further weathering in HT climate would finally close at Ultisols with considerable amount of layer silicate minerals (Pal et al. 2014). In view of contemporary pedogenesis, it is difficult to reconcile that Ultisols would ever be weathered to reach an unproductive stage like in Oxisols with time (Pal et al. 2014) as envisaged by Smeck et al. (1983) and Lin (2011). In view of their successful use for food production for centuries would it be prudent to consider such acid soils as degraded? This warrants for a revision in the present methodology giving due recognition of their pedogenetic processes that do not drive to an unproductive stage of soils.

\section{Resilience and Sustainability of Soils}

It is essential to develop through research the causeeffect relationship of the soil degradation and such basic knowledge enables the land resource managers to invent appropriate management protocols to make degraded soils resilient. At present such knowledge is available for degraded soils of both SAT and HT environments.

\section{Resilience and sustainability of naturally degraded $S A T$ soils}

The adverse SAT climatic conditions during the Holocene induce precipitation of $\mathrm{CaCO}_{3}$ with a concomitant development of sodicity in the subsoils of the SAT region. The subsoil sodicity impairs the saturated hydraulic conductivity ( $\mathrm{sHC}$ ) of soils, and as a result many soils of the Peninsular India suffer from loss of productivity (Pal et al. 2013). However, such soils show enough resilience under the improved management even when they are not endowed with soil modifiers such as Ca-zeolites and gypsum.

\section{A management protocol to make calcareous and sodic deep black soils (Vertisols) resilient}

SAT Vertisols (Sodic Haplusterts) that are not endowed with natural zeolite and gypsum, show poor saturated hydraulic conductivity $(\mathrm{sHC})\left(<10 \mathrm{mmhr}^{-1}\right)$ even at ESP $\geq 5$ $<15$, and have poor crop productivity, and are impoverished in organic carbon (OC) but are rich in $\mathrm{CaCO}_{3}$, and show enough resilience under improved management (IM) system of the ICRISAT (International Crops Research Institute for Semi-Arid Tropics) (Wani et al. 2003). The IM system does not include any amendment like gypsum and FYM. The average grain yield of the IM system over thirty years was five times more than that in the traditional management (TM) system. Adaptation of the IM system improved physical, chemical and biological properties of soils to the extent that a poorly drained black soil (Sodic Haplusterts) can now qualify for well-drained soil (Typic Haplusterts). A continuous release of higher amount of $\mathrm{Ca}^{2+}$ ions during the dissolution of $\mathrm{CaCO}_{3}(8.4 \mathrm{mg} / 100 \mathrm{~g}$ soil/year in $1 \mathrm{~m}$ deep profile) under the IM system, compared to slower rate of formation of $\mathrm{CaCO}_{3}(0.10 \mathrm{mg} / 100 \mathrm{~g}$ soil/year in $1 \mathrm{~m}$ profile $)$, provide enough soluble $\mathrm{Ca}^{2+}$ ions to replace unfavourable $\mathrm{Na}$ ions on the soil exchange sites. Higher exchangeable $\mathrm{Ca} / \mathrm{Mg}$ ratio in soils under IM system improved the $\mathrm{sHC}$ for better storage and release of soil water during dry spell between rains. Adequate supply of soil water helped in better crop productivity and higher OC sequestration. The improvement in Vertisols' sustainability suggests that the IM system is capable of mitigating the adverse effect of climate change. This management protocol though very slow as compared to gypsum-aided one, is however a cost-effective and farmerfriendly, and also helps land resource researchers to realize the benefit of the presence of $\mathrm{CaCO}_{3}$ as a hidden treasure in making degraded soils resilient. 


\section{Calcium carbonates make IGP sodic soils resilient}

When reclaimed with gypsum, some sodic soils (Natrustalfs) become resilient as reflected in their improved morphological, physical and chemical properties so much that these soils can now be reclassified as well-drained and OC-rich normal Alfisols (Haplustalfs) with remarkable enhancement in rice-wheat productivity. Generally, gypsum as amendment is added in relatively less amount than estimated by 'Gypsum Requirement' of highly sodic soils with ESP 90-100 (Natrustalfs) (Pal 2013). But even with the low amount of added gypsum, sodic soils are reclaimed to show their resilience. Gypsum added does not enrich soil solution by the required amount of $\mathrm{Ca}^{2+}$ ions to replace $\mathrm{Na}$ ions on the soil exchange sites. In fact, the $\mathrm{Ca}$ requirement to replace all exchangeable $\mathrm{Na}^{+}$ions is mainly through the rapid dissolution of the native pedogenic $\mathrm{CaCO}_{3}(\mathrm{PC})$ during the growing of the rice crop under submerged conditions. The rate of dissolution of PC during 30 months' cultural practice with gypsum in Natrustalfs has been estimated to be 254 $\mathrm{mg} / 100 \mathrm{~g}$ soil in the top $1 \mathrm{~m}$ of the profile. This indicates a much higher rate of dissolution $(\sim 100 \mathrm{mg} / 100 \mathrm{~g}$ soil/year) (Pal et al. 2009) than its rate of formation $(0.86 \mathrm{mg} / 100 \mathrm{~g}$ soil/year) in the top $1 \mathrm{~m}$ soil depth (Pal et al. 2000). The formation of PC causes the development of sodic soils (Pal et al. 2000) but its unique role in minimizing the cost of gypsum aided reclamation process and also making sodic soils resilient, adds to the present knowledge on resilience of degraded SAT soils of India and elsewhere.

\section{Gypsum makes SAT Vertisols resilient}

Under rain-fed situation, continuous efforts to grow cotton, pigeon pea and sorghum in Gypsic Vertisols of the SAT southern India indicate no development of sodicity (ESP $<5)$ in the profile despite the rapid formation of $\mathrm{CaCO}_{3}$, due to much faster solubility of gypsum than $\mathrm{CaCO}_{3}$. At present gypsum helps to mitigate the adverse effect of climate change from humid to semi-arid during the Holocene. The present sustainability of crop productivity in such soils would however be further improved by using good quality irrigation water so long gypsum remains available with time. In absence of gypsum these soils would lose sustainability as they would turn out to be sodic with poor drainage. Research on long-term experiments in calcareous Vertisols but naturally endowed with gypsum is needed, which may suggest how long an amount of gypsum would help in sustaining the present agricultural crop productivity by mitigating the adverse effect of $\mathrm{PC}$ under SAT environment.

\section{$\mathrm{CaCO}_{3}$ as soil modifier in ensuring sustainability of $\mathrm{SAT}$ soils}

After becoming non-sodic in nature through cultural practices, both IGP soils (Haplustalfs) and Vertisols (Haplusterts) have substantial stock of $\mathrm{CaCO}_{3}$ (as soil inorganic carbon, SIC) in the first $1.5 \mathrm{~m}$ depth, which has potential to improve the drainage, establishment of vegetation, and also sequestration of $\mathrm{OC}$ in soils (Pal et al. 2009). The continuance of agronomic practices of the NARS (National Agricultural Research Systems) and ICRISAT can provide the most important $\mathrm{Ca}^{2+}$ ions both in solution and exchange sites of soil. These resilient soils still contain nearly $2-7 \% \mathrm{CaCO}_{3}$. In view of the rate of its dissolution $(\sim 100$ $\mathrm{mg} / 100 \mathrm{~g}$ soil/year for IGP soils, and $21 \mathrm{mg} / 100 \mathrm{~g}$ soil/ year for Vertisols (Pal et al. 2012a, 2015), it is envisaged that under improved management in the SAT environment, total dissolution of $\mathrm{CaCO}_{3}$ would take a time of couple of centuries. Such chemical environment would not allow both Haplustalfs and Haplusterts to transform to any other soil order so long $\mathrm{CaCO}_{3}$ would continue to act as a soil modifier (Pal et al. 2012a, 2015). Positive role of $\mathrm{CaCO}_{3}$ in both reclamation and sequestration of $\mathrm{OC}$ in SAT soils may benefit maintaining the soil health of the farmlands if additional financial support through national and international initiatives including the incentives or transferable $\mathrm{C}$ credits under CDM is made available (Pal et al. 2015) to stake holders of sodic soils.

\section{Resilience and sustainability of HT soils}

Acidic Alfisols, Ultisols and Mollisols do respond to management interventions and support luxuriant forest vegetation, horticultural, cereal crops, tea, coffee and spices (Sehgal 1998), and thus contribute substantially to India's growing self-sufficiency in food production and food stocks (Chandran et al. 2005). In view of such reality, it would not be prudent to class them as chemically degraded soils with poor fertility. These soils do show their ability to stall the drastic chemical and mineralogical changes under intense HT climatic conditions for the last several millions of years (Pal et al. 2014). Questions remain how such soils are able to withstand the progressive pedogenesis in HT climate that would have otherwise made these soils to Oxisols, which are 
notorious in supporting crop productivity. An explanation is provided in the following paragraph.

In soils (developed on rocks/sediments rich in feldspar, zeolites and other Ca-rich minerals) of HT climate of India, the dominance of kaolin (smectite-kaolinite or vermiculite-kaolinite mixed layer minerals) indicates that in spite of prolonged weathering for millions of years, the weathered products of Ca-rich minerals of the parent materials have not reached even the pure kaolinitic mineral stage. The formation of kaolin clay mineral suggests that the formation of acidic Alfisols, Mollisols and Ultisols, and their pedogenic threshold at this time supports the supposition that steady state may exist in soils developed over long periods of time spanning not just thousands of years (Smeck et al. 1983; Yaalon, 1975) but also millions of years (Bhattacharyya et al. 1993, 1999; Chandran et al. 2005). Therefore, the formation and persistence of these soils provide an example that in an open system such as the soil, the existence of a steady state seems a more useful concept than based on equilibrium in a rigorous thermodynamic sense (Smeck et al. 1983; Bhattacharyya et al. 1999, 2006; Chandran et al. 2005), and Jenny's state factor equation is essentially valid. This contention finds support from the current pedogenetic processes in Ultisols in NEH areas. The OC rich Ultisols have less Al-saturation in surface horizons due to the downward movement of $\mathrm{Al}$ as organo-metal complexes or chelates, but have higher base saturation than the sub-surface horizons due to addition of alkaline and alkaline metal cations (Pal et al. 2014) through litter fall (Nayak et al. 1996), and there is no desilication and transformation of kaolin to gibbsite.

In Ultisols, Alfisols and Mollisols of HT climate, C sequestration is relatively high as indicated by their OC concentration ranges from 1.0 to 5\% (Pal et al. 2014)). Soils in a wet climate under forest have high OC content, sufficient to qualify as Mollisols. The OC addition to Ultisols and Alfisols has been possible as a result of, favourable soil temperature and moisture regime. It is known that 2:1 expanding clay minerals provide higher surface area for $\mathrm{OC}$ accumulation. But a high positive balance of OC in kaolin dominated soils clearly indicates a positive role of this mineral and other hydroxy-interlayered clay minerals because kaolin often shows a relatively high value of CEC $\sim 30 \mathrm{cmol}(\mathrm{p}+) \mathrm{kg}$ - 1(Ray et al. 2001) than that of well crystalline kaolinite. Therefore, besides the dominating effect of humid climate in cooler winter months with profuse vegetation, the soil substrate quality in terms of larger surface area is of fundamental importance in OC sequestration in soils, an important issue in maintaining soil health and sustainability (Velayutham et al. 2000; Pal et al. 2014). This has been possible due to considerable chemical reactivity of soil kaolin that helps provide an effective substrate to support agriculture and other land uses in the tropics. Soil kaolin provides the intrinsic ability to regenerate the productivity of these acid soils, thus making them resilient. Therefore, to sustain crop productivity at an enhanced level, large tracts of lands dominated by acid soils can be brought under improved soil, water and nutrient management to help meet the food needs of ever increasing Indian population and elsewhere of the tropical world (Pal et al. 2014: Gilkes and Prakongkep 2016).

\section{Epilogue}

To make degraded soils resilient, the basic information on cause-effect relationship of soil degradation is essential. The establishment of cause-effect relationship needs to be developed on identification of basic pedogenic processes that are linked to regressive and progressive pedogenesis in SAT and HT climates, respectively. Such gain in knowledge can equip well the land resource managers to develop the innovative management protocols for making degraded soils (with and without soil modifiers), resilient and sustainable. Regressive pedogenesis in SAT soils minimizes both soluble and exchangeable $\mathrm{Ca}^{2+}$ ions that impair their productivity. On the other hand despite their remarkable acidity, the unique presence of kaolin in the OC-rich acidic Alfisols, Mollisols and Ultisols formed during progressive pedogenesis in HT climate makes them resilient, helps in sustaining the agricultural, horticultural and forestry activities, and also in sequestering $\mathrm{OC}$ and removing the myth of their poor fertility. Studies on 'Soil resilience' and 'quality soil management' for enhanced 'soil quality' and sustainable land use management practices may focus on :

1. Long term fertilizer experiments and Nutrient Buffer capacity of soils

2. Long term crop rotation experiments and bioremediation techniques

3. Soil site-crop suitability matching and development of 'soil productivity index' and 'land quality index' for crops. 
4. IPNS practices for building up organic carbon content of soils to at least $1 \%$ level.

The following axiom in the 'Atharva veda', as if the ploughman speaks to the Mother Earth underlines the message of upgrading soil resilience by adopting 'quality soil management' practices:

"What of thee I dig, let that quickly grow over

Let me not hit thy vitals or thy heart"

\section{Acknowledgment}

Authors thank several researchers, especially those in the ICAR-NBSS \& LUP, Nagpur, India, whose studies over years helped in understanding the soil forming processes, resultant soil properties and sustainable land management strategies to be adopted for enhancing soil resilience.

\section{References}

Balpande, S.S., Deshpande, S.B. and Pal. D.K. (1996). Factors and processes of soil degradation in Vertisols of the Purna Valley, Maharashtra, India. Land Degradation and Development 7, 313-324.

Bhattacharyya, T., Pal, D.K. and Deshpande, S.B. (1993). Genesis and transformation of minerals in the formation of red (Alfisols) and black (Inceptisols and Vertisols) soils on Deccan Basalt in the Western Ghats, India. Journal of Soil Science 44, 159-171.

Bhattacharyya, T., Mukhopadhyay, S., Baruah, U. and Chamuah, G.S. (1998). Need for soil study to determine degradation and landscape stability. Current Science 74, 42-47.

Bhattacharyya, T., Pal, D.K. and Srivastava, P. (1999). Role of zeolites in persistence of high altitude ferruginous Alfisols of the humid tropical Western Ghats, India. Geoderma 90, 263-276.

Bhattacharyya, T., Pal, D.K., Lal, S., Chandran, P. and Ray, S.K. (2006). Formation and persistence of Mollisols on zeolitic Deccan basalt of humid tropical India. Geoderma 146, 609-620.

Bhattacharyya, T., Babu, Ram, Sarkar, D., Mandal, C., Dhyani, B.L. and Nagar, A.P. (2007). Soil loss and crop productivity model in humid tropical India. Current Science 93, 1397-1403.

Bhattacharya, T. et al., (2013) Soils of India: Historical perspective, Classification and recent advances: Current Science 104 (10):1308 - 1323
Bhattacharya, T. and Pal, D.K., (2014) Georeferenced soil information system for agricultural land use planning Current Science 107 (9) P.1400 - 1564

Bhattacharyya, T., (2014). Pedology: The grammar of soil science, The 32nd Prof. J. N. Mukherjee ISSS Foundation Lecture, Acharya N.G. Ranga Agricultural University, Hyderabad, 2014.

Chandran, P., Ray, S.K., Bhattacharyya, T., Srivastava, P., Krishnan, P., Pal, D.K. (2005). Lateritic Soils of Kerala, India: their mineralogy, genesis and taxonomy. Australian Journal of Soil Research 43, 839-852.

Chandran, P., Ray, S.K., Bhattacharyya, T., Tiwari, P., Sarkar, D., Pal, D.K., Mandal, C., Nimkar, A., Maurya, U.K., Anantwar, S.G., Karthikeyan, K and Dongare, V.T. (2013). Calcareousness and subsoil sodicity in ferruginous Alfisols of southern India: an evidence of climate shift. Clay Research 32, 114-126.

FAO (Food and Agriculture Organization of the United Nations), (1994). Land Degradation in South Asia: its Severity, Causes and Effects upon the People. World Soil Resources Report No. 78, FAO, Rome, Italy.

Hall, G.F., Daniels, R.B. and Foss, J.E., (1982). Rates of soil formation and renewal in the USA. In: Schmidt, B. L. (Ed.), Determinants of Soil Loss Tolerance. ASA Publication No. 45. American Society of Agronomy, Madison, Wisconsin, USA, pp. 23-29.

Gilkes, R.J. and Prakongkep, N. (2016). How the unique properties of soil kaolin affect the fertility of tropical soils. Applied Clay Science.

ICAR-NAAS (Indian Council of Agricultural ResearchNational Academy of Agricultural Sciences) (2010). Degraded and Waste lands of India-Status and Spatial Distribution. ICAR-NAAS. Published by the Indian Council of Agricultural Research, New Delhi, 56 pp.

Jenny, H., and Raychaudhuri, S. P. (1960). Effect of climate and cultivation on nitrogen and organic matter reserves in Indian soils. Indian Council of Agriculture Research, New Delhi, 126 S., 32 Tab., 33 Fig. (1960).

Kassam, A.H., van Velthuizen, G.W., Fischer, G.W. and Shah, M.M. (1992). Agro-ecological land resource assessment for agricultural development planning: 
a case study of Kenya resources data base and land productivity. Land and Water Development Division, Food and Agriculture Organisation of the United Nations and International Institute for Applied System Analysis, Rome.

Lin, H. (2011).Three principles of soil change and pedogenesis in time and space. Soil Science Society of America Journal 75, 2049-2070.

Mosi, Dhanapalan., Janakiraman, M. and Eswaran, H. (1991). Communicating soil survey information to traditional farmers. Soil Survey Horizons, USDA. pp. 31-33.

Nayak, D.C., Sen, T.K., Chamuah, G.S. and Sehgal, J.L. (1996). Nature of soil acidity in some soils of Manipur. Journal of Indian Society Soil Science 44, 209-214.

Oldeman, L.R., (Ed.), (1988). Global Assessment of Soil Degradation (GLASOD). Guidelines for General Assessment of Status of Human-Induced Soil Degradation. ISRIC, Wageningen, the Netherlands.

Pal, D.K., Dasog, G.S., Vadivelu, S., Ahuja, R.L. and Bhattacharyya, T. (2000). Secondary calcium carbonate in soils of arid and semi-arid regions of India. In Lal, R., Kimble, J.M., Eswaran, H., Stewart, B. A.(Eds.), Global Climate Change and Pedogenic Carbonates, Lewis Publishers, Boca Raton, USA, pp.149-185.

Pal, D. K, et al. (2000). Significance of minerals in soil environments of India NBSS Review series 1, P.68, NBSS\&LUP Nagpur.

Pal, D.K., Srivastava, P. and Bhattacharyya, T. (2003). Clay illuviation in calcareous soils of the semi-arid part of the Indo-Gangetic Plains, India. Geoderma, 177-192.

Pal, D.K., Bhattacharyya, T., Ray, S. K., Chandran, P., Srivastava, P., Durge, S. L. and Bhuse, S.R. (2006). Significance of soil modifiers (Ca-zeolites and gypsum) in naturally degraded Vertisols of the Peninsular India in redefining the sodic soils. Geoderma 136, 210-228.

Pal, D.K., Bhattacharyya, T., Chandran, P. and Ray, S.K. (2009). Tectonics-climate-linked natural soil degradation and its impact in rainfed agriculture: Indian experience. In: Wani, S.P., Rockstroem, J., Oweis, T. (Eds.), Rainfed Agriculture: Unlocking the Potential, CABI International, Oxfordshire, U.K., pp.54-72.
Pal, D.K., Wani, S.P. and Sahrawat, K. L. (2012a). Vertisols of tropical Indian environments: Pedology and edaphology. Geoderma 189-190, 28-49.

Pal, D. K., Sarkar, D., Bhattacharyya, T., Datta, S.C., Chandran, P. and Ray, S. K. (2013). Impact of climate change in soils of semi-arid tropics (SAT). In: Bhattacharyya, T. et al. (Eds.), Climate Change and Agriculture, Studium Press, New Delhi, pp.113-121.

Pal, D. K. (2013). Soil modifiers: their advantages and challenges. Clay Research 32, 91-101.

Pal, D.K., Wani, S. P., Sahrawat, K. L. and Srivastava, P. (2014). Red ferruginous soils of tropical Indian environments: A review of the pedogenic processes and its implications for edaphology. Catena, 121, 260-278. DOI: $10.1016 / j$. catena 2014.05.023.

Pal, D.K., Wani, S.P. and Sahrawat, K.L. (2015). Carbon sequestration in Indian soils: Present status and the potential. Proceedings of the National Academy of Sciences, Biological Sciences ( N A S B ), I n d i a , 85,337 358..DOI:10.1007/s40011-014-0351-6

Pathak, P., Singh, S. and Sudi, R. (1987). Soil and water management alternatives for increased productivity on SAT Alfisols. Soil Conservation and Productivity. Proceedings IV International Conference on Soil Conservation, MaracayVenezuela, November 3-9, 1985, pp. 533-550.

Pathak, P., Sudi, R., Wani, S.P. and Sahrawat, K.L. (2013). Hydrological behaviour of Alfisols and Vertisols in the semi-arid zone: implications for soil and water management. Agricultural Water Management $118,12-21$.

Ray, S.K., Chandran, P. and Durge, S.L. (2001). Soil taxonomic rationale: kaolinitic and mixed mineralogy classes of highly weathered ferruginous soils. Abstract, 66th Annual Convention and National Seminar on "Developments in Soil Science" of the Indian Society of Soil Science, Udaipur, Rajasthan, pp. 243-244.

Sehgal, J.L. (1998). Red and lateritic soils: an overview. In: Sehgal, J., Blum, W.E., Gajbhiye, K.S. (Eds.), Red and Lateritic Soils. Managing Red and Lateritic Soils for Sustainable Agriculture, Vol.1. Oxford and IBH Publishing Co. Pvt. Ltd., New Delhi, pp. 3-10. 
Sehgal, J.L. and Abrol, I.P. (1994). Soil Degradation in India: Status and Impact. Oxford \& IBH Publishing Co. Pvt. Ltd, New Delhi, India.

Smeck, N.E., Runge, E.C.A. and Mackintosh, E.E. (1983). Dynamics and genetic modeling of soil system. In: Wilding, L.P., Smeck, N. E., Hall, G. F. (Eds.), Pedogenesis and Soil

Srivastava, P., Pal, D.K., Aruche, K.M., Wani, S.P. and Sahrawat, K.L. (2015). Soils of the Indo-Gangetic Plains: A pedogenic response to landscape stability, climatic variability and anthropogenic activity during the Holocene. Earth-Science Reviews 140, 54-71. doi: 10.1016/j.earscirev.2014.10.01

Swarup, A.,. Manna, M.C. and G.B. Singh (2000). Impact of land use and management practices on organic carbon dynamics in soils of india. Page 261-281 In R.Lal et al. (Eds). Advances in Soil Science. Global Climate Change and Tropical ECO Systems. CRC/Lewis Publishers Boca Raton, FL.USA.
Szabolcs, I. (1994). Concepts of soil resilience in: Soil resilience and sustainable land use. In: Greenland, D. J., Szabolcs, I. (Eds.), Wallingford, UK, CAB International.

Vaidya, P.H. and Pal, D.K. (2002). Microtopography as a factor in the degradation of Vertisols in central India. Land Degradation and Development 13, 429-445.

Velayutham, M., Pal, D.K. and Bhattacharyya, T. (2000). Organic carbon stock in soils of India. In: Lal, R., Kimble, J.M., Stewart, B.A. (Eds.), Global Climate Change and Tropical Ecosystems. Lewis Publishers, Boca Raton, Fl, pp. 71-96.

Wani, S. P., Pathak, P., Jangawad, L. S., Eswaran, H. and Singh, P. (2003). Improved management of Vertisols in the semi-arid tropics for increased productivity and soil carbon sequestration. Soil Use and Management 19, 217-222.

Yaalon, D.H. (1975). Conceptual models in pedogenesis. Can soil forming functions be solved? Geoderma 14, 189-205.

Received : January, 2016

Accepted : April, 2016 